\title{
ESL Students Speak Up: Their Stories of How We Are Doing 1
}

\section{Yasuko Kanno and Sheila Dermer Applebaum}

This study explores the ESL curriculum as experienced by students, casting light on their side of the story. We invited three Japanese secondary-level students to discuss their experience of learning English and analyzed their stories in terms of Schwab's four curriculum commonplaces (learner, subject matter, milieu, and teacher). Our analysis reveals that for the students, learning English has to do with negotiating their identities in a new environment. The current ESL curriculum as it focuses on the development of academic skills may not be providing enough support to help them integrate into the school community. In the absence of such support, some students may run the risk of perpetuating their marginality in the school and prematurely reaching a plateau in their English acquisition. Some practical ideas to promote integration, some of which are already implemented in Canadian schools, are discussed in the light of these findings.

\section{Introduction}

We start with a premise that not enough student voice is reflected in the discussion of ESL education. As educators, teachers, and researchers we spend inordinate amounts of time discussing theories, instruction methods, materials, and program evaluation. In comparison, we do not seem to spend nearly as much time asking ourselves what it is like for ESL students to learn English. Although several studies approaching ESL education from the point of view of student empowerment (Cummins, 1989; Wong Fillmore, 1983; Wong Fillmore \& Meyer, 1992) illuminate some important aspects of student experience, they tend to come from an adult's perspective. A few researchers, fortunately, are now starting to explore ways of incorporating student experience into the ESL research (Early, 1992; Harklau, 1994). One of them, Early (1992), observes that "ESL students' perceptions of their educational experiences are an enormously rich, untapped source of data" (p. 274).

This study is part of the emerging efforts represented by such researchers as Early and Harklau to cast light on ESL students' views of their experiences. The study argues that qualities of human experience in ESL education deserve more attention than they have been granted so far and that examining students' stories of experience is an integral part of understanding the educational values of the current ESL curriculum. In stating this, what we have in mind is Dewey's (1938/1963) notion of educative experience-one that is conducive to the learner's educational and personal growth. Central to 
our discussion are the stories of three Japanese secondary-level students who experienced various ESL programs in Toronto. The analysis of their stories reveals that learning English for them is inextricably intertwined with establishing their identities in a new environment. When ESL experience is viewed this way, a gap between what ESL students need to learn and what current ESL programs offer becomes apparent. In what way can we narrow this gap? After an analysis of four dimensions of student experience, we describe some of the existing strategies for promoting integration and point to areas that need further enhancement.

\section{Toward Capturing Student Experience}

It is not hard to understand why ESL researchers have not paid much attention to the ESL curriculum as experienced by students. One reason has to do with the current strong tendency of SLA research to emulate natural science. Metaphors borrowed from natural science such as measurement, general laws, and control may have diverted SLA researchers from stepping into the realm of meaning and interpretation. Although the last 20 years of SLA research has revealed a great deal about L2 learners (Larsen-Freeman, 1991), what has been revealed is not so much the learners' experiences as the effects of learner variables such as aptitude, strategies, motivation, age, and first language on the process and result of $\mathrm{L} 2$ acquisition. The focus has been on the phenomenon of L2 acquisition, not on "the living individual human being" (Conle, 1992, p. 165).

Another reason for the absence of research on ESL students' experiences is that students generally have the least power among all the stakeholders in any given curriculum. Erickson and Shultz (1991) argue that "the commonsense view of educational practice, of what is most important to pay attention to in and about schools, has left little room indeed for the points of view of the very persons who are the first-level consumers of educational services" (p. 481). ESL education is no exception to the rule. Moreover, ESL students are doubly liable to be silenced given their minority backgrounds and lack of English proficiency. The vast majority of ESL students may not even think that they have the right to voice their opinions, as we see below.

The difficulty lies in breaking away from the long-established mode of research in which the researcher alone determines what information should be gathered and how; not only does the researcher expect to lead, but the participant also expects to be led. At the beginning of this project we often found it difficult to let go of the control over the interview. Our participants were also liable to ask, "What do you want to know?" However, we were willing to learn to listen, and our participants, once they were convinced of our genuine interest, had no shortage of stories to tell.

It soon became clear to us that we researchers currently have little idea of what really matters to ESL students. It is as if ESL researchers and ESL 
students each mind their own business and never the twain shall meet. For the students we approached the ESL curriculum was never just about learning English. Rather, it involved critical issues such as their identities in school and their interpersonal relationships with other people. We felt the need to introduce their perspective into ESL education discourse in a way that informs both theory and practice.

Although we could have chosen to tell the students' stories in a straightforward manner, we believed that a more meaningful representation was possible. In particular, we wanted to constitute a narrative that reflected an interplay of the internal conditions of the individual and the external conditions of the environment (Dewey, 1938/1963). For this reason we adopted Schwab's $(1971 ; 1973)$ four commonplaces-learner, subject matter, milieu, and teacher-as analytical tools. These commonplaces constitute four major pillars of every curriculum and thus "an adequate curriculum statement must say something about each of them" (Connelly \& Clandinin, 1988, p. 84). By throwing light on the same curriculum experience from four different angles we began to understand the complex nature of the relationship between learner and context.

\section{Participants}

The participants in this study were three Japanese students who attended secondary schools in Metropolitan Toronto (see Figure 1 for the summary of their backgrounds). Ritsuko, Saori, and Kenta (pseudonyms) were grade 12 students when the first author made initial contact with them. They were children of Japanese businessmen who were on temporary overseas assignment in Canada. They came from middle- to upper-middle-class backgrounds. Their sojourns in Toronto as well as in other places were all initiated by their fathers' job transfers. Ritsuko and Saori each stayed in Toronto for two years (with both of them having previously lived in the United States) while Kenta stayed for six and half years. While in Toronto they attended local Canadian secondary schools during weekdays and a Japanese supplementary school on Saturdays. The latter was for first language maintenance and for catching up with the Japanese curriculum. They returned to Japan on completing secondary school.

It must be emphasized that these students did not intend to stay in Canada permanently. For this reason, they constitute a categorically different group from immigrant students in terms of language learning. That is, they had less motivation to approach the learning of English as a lifetime commitment than immigrant students and, conversely, had more practical incentives to maintain their first language. Despite such differences, however, we feel that a number of issues illuminated by their experiences are relevant to immigrant students, especially those who have recently arrived from the Far East. 
The data used for this study were taken from in-depth free-conversationstyle interviews the first author conducted with the students at various points during the past three years. The number of interviews with each student ranged from five to 10 , each interview lasting anywhere from one and a half hours to three hours. All interviews were in Japanese and were later translated into English. Earlier versions of this article were shared with the participants for correction and feedback.

\section{Stories}

\section{Ritsuko}

Ritsuko moved to Los Angeles when she was 7. Few other Japanese lived in Los Angeles at that time and her family settled down in a white middle-class neighborhood. In school she was mainstreamed from the beginning. Like many young minority children living in North America, it did not take Ritsuko long to assimilate into American life. By the end of three years her conversation with her younger brother was mostly in English, she says.

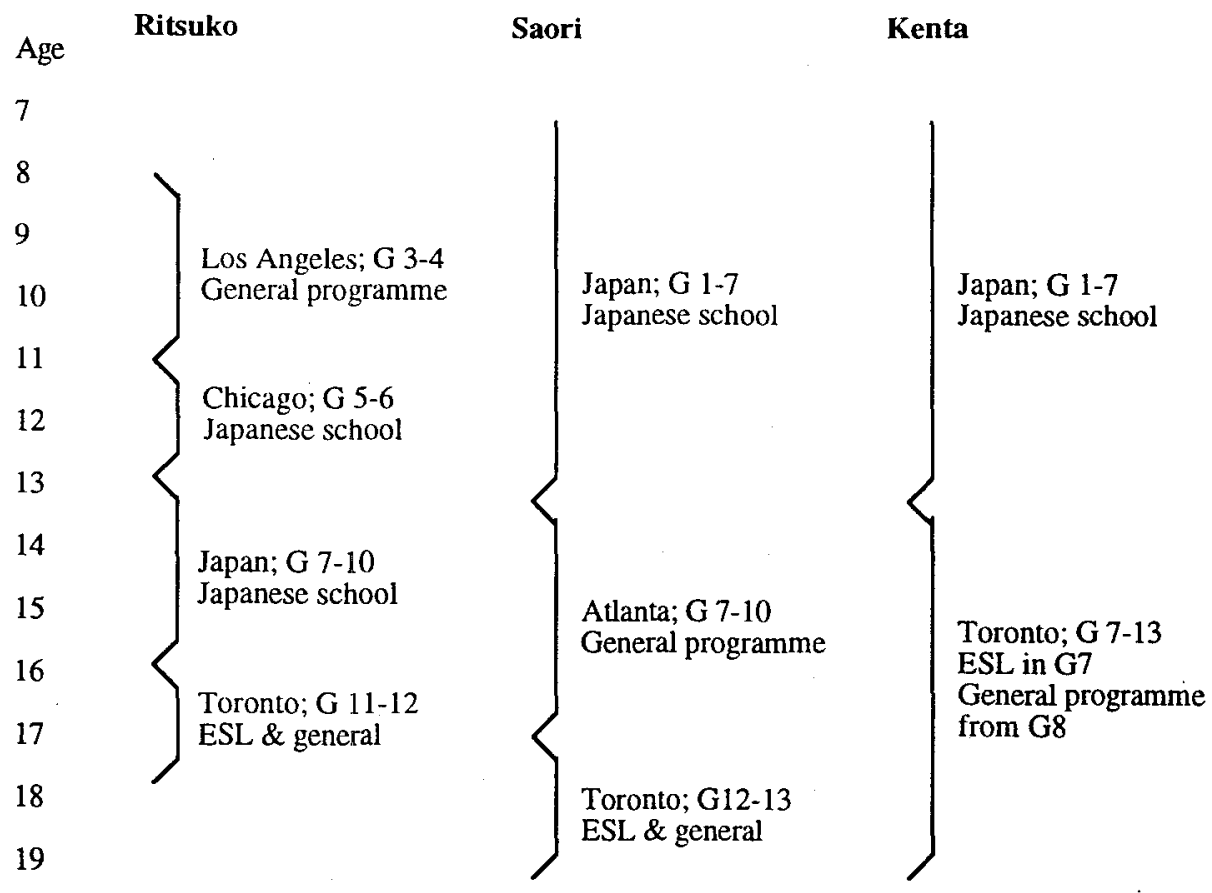

FIGURE 1. Summary of the three Japanese students' backgrounds. 
"Had I stayed there," she muses, "I would have become like a JapaneseAmerican."

After three years Ritsuko and her family moved to Chicago where she went to a full-time Japanese school. Her parents, who were worried about the rapid attrition of her Japanese, decided to forgo the regular American school. Virtually all the students in her new school were Japanese temporary sojourners like herself, and all the subjects except English were taught in Japanese. This meant that Ritsuko spoke Japanese both at home and at school. She quickly became dominant in Japanese once again.

She returned to Japan when she was in grade 7 , and for the next three years she experienced a taste of Japanese junior high school and high school. When she was in grade 11 her father decided to take on another overseas assignment. Thus started her sojourn in Toronto.

Ritsuko expected her life in Toronto to be like that she had experienced in Los Angeles: quick assimilation into the host culture and friends from the white middle-class background. But it took on a very different color. Her new school offered a variety of ESL courses, not only in English but also in other subjects. Apprehensive about her English after five years of little practice, she decided to try ESL first until she regained the knack of using English. That was, she says, a big mistake: "I thought that I'd try ESL only for a short time ... but [once I was in it,] it was too late. Japanese are really cliquey there and I couldn't get out. I got trapped." She discovered too late that because of the extensive ESL system, little interaction took place between ESL and native-English-speaking students in her school. With the ESL students taking ESL courses and the English-speaking students taking general (i.e., non-ESL) courses, they hardly met each other. The psychological barrier between the two groups made it difficult for Ritsuko to make a transition into the general program. She opted for ESL courses whenever possible, making friends exclusively with other ESL students. She feels that she could have learned more English had she ventured out of the ESL setting more often.

\section{Saori}

Saori moved to Atlanta at the age of 13 , having completed elementary school in Japan. She had just started learning English in junior high school, but when she arrived in Atlanta she found herself placed in a mainstream American classroom, where it was up to her to either sink or swim. Few immigrant families lived in her neighborhood so there was not enough demand for setting up formal ESL classes. She did not find her American classmates too friendly: "They had this attitude, 'What's the point of speaking to this girl? She won't understand anyway.'" She felt little obligation to learn English herself because it was not her decision to come to the States in the first place. She does not recall a single person in her American school whom she would call a friend. 
Whatever needs that could not be fulfilled in her English worldfriendship, emotional support, self-esteem, recognition for her intelligence, and more-she sought in her Japanese world. She bought Japanese books and rented videos of Japanese TV programs on a regular basis. She turned to her mother-she was an only child-as the sole viable communication partner during weekdays. Going to the supplementary school on Saturdays was the highlight of the week because she could speak Japanese with other Japanese students to her heart's content. An additional bonus there was that she suffered none of the disadvantages of studying in a second language. As long as everything was taught in Japanese she had no problem being a top student.

Saori's father was transferred to Toronto when she was in grade 11. By then she had lost interest in English speakers altogether. What she wanted were Japanese friends, people she could communicate with in her native language. Her new school was an ideal place in that respect, because it had a number of Japanese students of her age. Meeting them after four years of impoverished social contact was like a rediscovery of her "lost Japanese adolescence." With her newly acquired friends, Japanese now became the language of both home and school. At home she read Japanese books, watched Japanese videos - her family rented more than 300 videos in less than two years-and spoke Japanese with her parents; in school she gossiped about Japanese pop stars with her friends, exchanged Japanese magazines and CDs, and discussed each other's daily concerns. In a place where the majority language was English the only time she spoke and listened to the language was when she was sitting in the classroom.

\section{Kenta}

Kenta moved to Toronto when he was 13, around the same time as Saori left for Atlanta. Unlike the other two students, who moved from one city to another, Kenta stayed in Toronto until he returned to Japan. His attitude toward his sojourn was all-out positive from the beginning. He reacted to the news of his father's transfer with nothing short of euphoria: "I leapt with joy. I was just so happy. I really wanted to go abroad." Once in Toronto he deliberately chose a school where there were no other Japanese and set out to integrate himself into Canadian life.

Kenta's strong integrative motivation by no means spared him all the difficulties of learning a new language. Initially his lack of confidence in English inhibited him from doing things he wanted to do such as actively participating in school activities and approaching girls. But if he was behind everyone else in English, he had at least one thing he could do better than most: sports. He had been a keen baseball player in Japan, and sports became an important means of communication with Canadian peers. Being a good 
athlete was a definite asset in winning popularity with teenage boys; they flocked around Kenta and quickly accepted him as their buddy.

Having no shortage of communication opportunities, he became so proficient in colloquial English that by grade 12 some Canadians would take him for a Canadian-born. However, Kenta does not think of his environment as particularly conducive to good English learning. Both students and teachers were so accepting of him even when his English was still elementary, he says, that there was no need for him to polish his English beyond what was necessary to lead a comfortable school life. He believes that it would have been better for his English if he had been placed in a stricter environment where speaking English was forced on him for the sake of survival.

\section{Analysis of Students' Experiences by Schwab's Four Commonplaces}

\section{Learner}

A common thread that runs through the above stories is a strong connection between the learners' peer searching and their English learning. Searching for a viable peer group is no doubt on most teenagers' agenda, but for the ESL students who have just arrived in Canada it takes on a greater sense of urgency. Depending on whose friendship they seek, learning English becomes more or less important to them. If they seek the membership of a Canadian peer group, as did Ritsuko and Kenta, English is obviously an important language to learn. As Gardner and Lambert (1959) have long noted, integrative motivation enhances second language learning. If, on the other hand, the company of fellow compatriots is all that matters, as was the case with Saori in Toronto, learning English becomes peripheral in daily life. Saori's story serves as a reminder that we cannot underestimate the extent to which such students can minimize their use of English in many aspects of their lives. Teenagers are considerably more mobile than younger children; their social lives are no longer restricted to the immediate vicinity of their homes and school. With the use of a car and public transportation students of the same ethnic community can easily form a close-knit group even if they do not go to the same school.

Whether or not entry into a native-English-speaking students' peer group is deemed feasible also affects the ESL students' motivation to continue their English learning. Ritsuko arrived in Toronto with high motivation to learn English and to integrate into the native English speakers' community. But as soon as she realized that no effort on her part would open the door to the community, she lost her will to advance her English. Her experience points to the nature of integration as a reciprocal process of adaptation by newcomers to the norms of the host country and accommodation by the host country to the values brought by the newcomers (Employment and Im- 
migration Canada, 1992). In other words, no true integration will result in a situation lacking either condition.

\section{Subject Matter}

Turning now to subject matter, it is important to clarify first what kind of ESL program each of our three students underwent. Ritsuko, during her two years of sojourn in Toronto, took not only English but several other subjects as ESL courses. Saori received no formal ESL instruction in the United States. After she moved to Canada she took two ESL courses, namely grade 11 English and grade 9 French. Kenta was placed in a pull-out ESL program in grade 7 , joining his Canadian classmates only in relatively language-independent subjects such as physical education and music. By grade 9 he had made a complete transition to the general program.

The Ontario Ministry of Education (1988) states that the goal of ESL education is "to give students the opportunity to develop the language skills and knowledge of the environment necessary for successful integration into the school and community" (p. 16). It defines the ESL program as a transitional stage by stating that "a student will take only as many ESL or ESD [English skills development] credits as he or she needs to be able to participate successfully in the regular program" (p. 6). Together these two statements suggest the integrative and temporary nature of ESL classes.

Our participants claim a wide discrepancy between theory and practice. Saori points out a lack of connection between the ESL and general programs: "What you do in ESL isn't really useful in the regular class ... I don't think that they [teachers] even mean it to be preparation for the regular class." Ritsuko also found the level of ESL classes far removed from that of non-ESL classes: "My [grade 12] ESL class was full of Chinese and Japanese, and we played games, had mah jongg tournaments. Every now and then we wrote poems but it was really easy. Even the most difficult book we read was the kind that people would read in grade 10 or $11 . "$

In terms of what they learned in the ESL programs, Saori, who had spent four years in the United States prior to coming to Canada, talked about a gap between what she needed to learn and what she was taught: "It was all like a review of what I already knew. I wouldn't say that it was utterly useless, but I felt that what I needed to learn was grammar and everyday conversation and we didn't do those. Things like reading books, discussing them, describing the plot, and writing summaries I could already do. I guess ESL courses are meant for people who need to do these things and so they weren't suited to people like me who had been in the States before."

Both Kenta and Ritsuko, who wanted Canadian peers, saw the ESL program as an impediment to their integration. As far as they were concerned, ESL programs divided rather than united students. Kenta said, 
I don't really know what I learned in the ESL program. I'd rather have studied together with my friends in my grade 7 and 8 homeroom classes... I think it would have been more useful for me to know, at the onset, the level of English my Canadian-born peers were dealing with. Instead, I was in an ESL class from the beginning, floating on the comfortable lukewarm water, when I should really have been a lot stricter with myself.

The same sentiment echoes in Ritsuko's words:

You go to [a non-ESL class] and sit with white people. You understand the content of the class, but when you have to find a partner and work on a group project, you can't get into a group. You feel too embarrassed to ask someone to be your partner. You feel like you're gonna be a burden on them. So you don't ask them; you wait until they ask you.

The discrepancy between theory and practice may be largely due to an inadequate assessment of current ESL students' needs. ESL programs have traditionally accommodated "students who, because of limited educational opportunity prior to coming to Canada, require upgrading in basic skills" (Toronto Board of Education, 1988, p. 14). Moreover, as Wong Fillmore (1989) points out, a pervasive assumption may be operating in schools that "students who are not proficient in English cannot handle more demanding subject matter" (p. 130). However, the recent immigration trends have brought about an influx of non-English-speaking students from the Far East who have been well educated in their countries of origin. ${ }^{2}$ If academic and cognitive aspects of language proficiency are transferable between a learner's first and other languages, as has been demonstrated by a series of studies by Cummins $(1979,1984)$, ESL students who already possess sophisticated cognitive academic language proficiency (CALP) in their first language may find ESL programs designed to develop basic academic skills redundant and unstimulating.

On the other hand, these same students may find developing basic interpersonal communicative skills (BICS, Cummins, 1979) in English substantially more difficult. All our three participants were earning a grade average higher than $70 \%$ by their final year in Toronto, while two of them, Ritsuko and Saori, had great difficulty handling interpersonal communication in English. BICS have traditionally received less attention than CALP in ESL education because they are deemed easier and less time-consuming to acquire (Collier, 1987; Cummins, 1984). But at least for some Asian students with highly developed academic skills in their first language, the trend is reversed. Unlike academic work in English, for which they can turn to their conceptual knowledge in their first language, the development of BICS involves learning culture-specific norms and expressions and thus requires interaction with native speakers. But how can they start interacting and 
developing friendships with native-speaking peers if they do not have the language for it in the first place? It is a vicious circle that is difficult to break. Research (Brislin, 1981; Furnham \& Bochner, 1986; Klein, Alexander, \& Tseng, 1971) shows that many students from the Far East have difficulty developing a viable social network with North Americans suggesting that among Asian ESL students Ritsuko and Saori, rather than Kenta, are the norm. It is important to note that Kenta's popularity among Canadian peers originated partly from his athletic abilities. Students like him who can resort to other means of communication such as sports and music may be able to develop peer relationships with native-speaking students. In this way they obtain communication opportunities vital for developing BICS. Students who do not have such alternative means of communication, however, may be led to isolation unless they are given extra support in this area.

ESL instruction, of course, does not have to be demeaning to the students' cognitive abilities, nor does it have to be socially isolating. In this context a project carried out in British Columbia called the Vancouver School Board Language and Content Project (Early, Mohan, \& Hooper, 1989; Early \& Tang, 1991; Dunbar, 1992; Tang, 1994) is worth noting. Early et al. (1989) argue that:

What is needed ... to help students bridge the gap between beginning social acquisition and full social and academic linguistic competency in the mainstream classroom is a carefully articulated approach and program which integrates the teaching of language and the teaching of subjectarea knowledge. (p. 108, emphasis added)

Tang (1994), for instance, describes a collaboration between an ESL teacher and a subject area teacher in designing and conducting a unit that combines ESL instruction and computer studies. Although this particular unit was designed for ESL students' class, the use of graphics and key visuals that Tang and others involved in the project promote must be helpful to anyESL or non-ESL_-students' learning and thus could be utilized effectively in the integrated class. Once we move beyond the mindset that English learning must precede content learning and seek instead the possibilities of combining both in the integrated curriculum, the lack of intellectual challenge and the sense of isolation from the native-speaking peers that our students reported may be effectively reduced.

\section{Milieu}

Critical educational theorist McLaren (1989) regards schools as "sites of both domination and liberation" (p. 167, original emphasis): they function "simultaneously as a means of empowering students around issues of social justice and as a means of sustaining, legitimizing, and reproducing dominant class interests directed at creating obedient, docile and low-paid future workers" (p. 167, original emphasis). This dialectical perspective on schools allows us 
to see the milieu of ESL education not as a culturally neutral territory where only the learning of English is an issue but as a site of intense negotiation between different identities. It contains conditions conducive to both educative experiences and miseducative experiences.

Let us start with the positive side. Canadian schools, Kenta says, provide students with enough time and security to take risks and venture into areas where they lack confidence. Compared with exam-oriented, highly competitive Japanese education, the curriculum in Canadian schools is generally more relaxed and process-oriented. Kenta believes that it helped him grow out of the quiet, insecure boy that he had been in Japan into a more active and self-confident young adult. "People here value you for going out there and doing things actively," he says. "It doesn't matter if you fail; the important thing is that you've tried." He recalls a speech contest he had to enter in grade 8: "It was only after two years of learning English and I thought there was no way I could pull it off. I was afraid that people would laugh at me. But actually they clapped when I finished. That made me think, 'I can manage somehow.'"

Yet Kenta feels that the same relaxed atmosphere also hindered the development of his English. He said, "Both teachers and other kids accepted me even when I didn't speak English." Kenta's experience reminds us of some of the ESL learners reported in Saville-Troike's (1984) study, who demonstrated early skill at developing interpersonal relations with English-speakers: "Some of the more successful communicators with English-speaking peers ... 'plateaued' at fairly early levels of development, suggesting that their very success may have reduced their motivation to learn more complex linguistic forms" (p. 210).

Kenta's lack of confidence in English, despite his apparent success in both academic subjects and interpersonal relations, intrigues us. It intrigues us even more when we see the same kind of insecurity in another participant. Saori, with an above- $80 \%$ grade average in high school, seems to feel that the high marks she was getting were somewhat fake. Comparing her position in the Japanese supplementary school with her position in her Canadian school, she said, "In the supplementary school I'm a top student. And it is the top student position that I have earned with legitimate means, isn't it? In my Canadian school I'm not as good, but they give me good marks for my effort anyway. The 90 -something I'm getting is really that, a reward for a student who is not very good but who is trying hard."

Schools as learning sites must strike a balance between being challenging and being comfortable in order to draw the maximum benefit from both. In the case of Kenta and Saori, they found the milieux in which they learned English too lax to bring out their full potential. More specifically, they did not receive enough "social or cognitive pressure to produce language that reflects more appropriately or precisely their intended meaning" (Swain, 
1985, p. 249). The nagging feeling that remains in both of them is that their English might have reached a higher ground had they been pushed a little harder. Falling short of the level of language proficiency they feel they should have attained, they never reached a point where they could say with confidence that English had become their language. This lack of the sense of ownership over English, we believe, is at the core of their persistent insecurities surrounding the language question. Six years of immersion, and English still remained someone else's language for them.

The milieu becomes least educative for ESL students when the sociocultural climate of the school pushes them to the margin. Unfortunately, the perception of ESL classes as remedial classes and ESL students as learning disabled students may be more prevalent among secondary school students than ESL educators wish to acknowledge. A small episode in Ritsuko's story is illustrative of this. One day she was doing a science experiment in a laboratory by herself during the lunch break. A Canadian student came to the room and yelled out, "Open the door." Ritsuko ignored this because she had been told by her science teacher not to let anyone else in. But the student kept banging on the door and eventually sneaked in through the back door, which was not locked. Fuming with anger, she shouted at Ritsuko, "Are you deaf or ESL!?" Ritsuko was shocked, but when she told this incident to a Chinese ESL student, his response was that of resignation: "Oh, just ignore them. You know, we hate Canadians; Canadians hate us, too."

A person's identity is shaped and reshaped through interaction with others (Mead, 1934; Taylor, 1992). Toohey (1992) points out our tendency to define ESL students in terms of deficiency, of their lack of language abilities, when in fact they are (at least) bilingual or on the way of becoming so. It is easy to imagine how such views are passed on to ESL students to form a negative self-image for them. Ritsuko and her friend reacted to the Canadian student's blatant insult with a sigh of resignation, as if they too believed that being an ESL student was a disgrace. They seemed to lack vocabulary for anger altogether. When asked if she ever felt angry about what she characterized as ESL students' marginalization in her school, Ritsuko said, "Yeah, sort of, but I can't do anything about it. There's no point in minorities standing up and fighting."

Perhaps it is high time we discarded our romantic notion that if we put children of all ethnic/linguistic backgrounds in one place we will witness the development of true cross-cultural understanding. A deep chasm can form between language majority and language minority students if the school makes no attempt to bring them together. Integration is not only for the sake of ESL students; it should also prepare students from the majority culture for the cultural and linguistic diversity that is rapidly becoming a fact of life in the country they live in. 
In the light of this, pairing a native-English-speaking student with an ESL student in a peer buddy system implemented in some Toronto schools appears to create a truly educative experience for both people. On the one hand, the buddy system can help eliminate strong feelings of alienation that seem to be currently common among ESL students and give them an avenue for entry into the wider community. On the other hand, it can sensitize nativespeaking students to the presence of others who are living outside of "white, middle-class, monolingual realities" (Cummins, 1992, p. 3) and help them learn to negotiate with people with markedly different identities. ${ }^{3}$

Another strategy that individual teachers can adapt in promoting integration is classroom management. This often has a large impact on shaping the culture of the classroom. If the natural tendency for students in the regular classroom setting when they are assigned a group project is to split up into groups of similar language proficiency levels, teachers can step in to mix students of different language backgrounds and levels. Mixing the groups provides an additional opportunity to develop language proficiency as well as interpersonal and collaboration skills for all parties. For ESL students in particular this would provide a valuable testing ground for their current English abilities and an excellent motivation for further development. Moreover, an increased opportunity to work with native speakers of English on a shared task could eliminate a common anxiety among ESL students-our three participants included-that they are not exposed to enough "real English."

\section{Teachers}

Individual teachers who have left a strong enough impression on our participants to appear in their stories are those who went out of their way to earn more recognition for ESL students and to ensure that their dignity be maintained. This goes to show that "a positive relationship with a caring adult who can be trusted is as important as peer relationships in helping students feel they are part of the school community" (Toronto Board of Education, 1991, p. 20). Students such as Ritsuko and Saori, who had difficulty establishing rapport with Canadian students, especially seemed to appreciate their teachers' support.

For instance, Saori told a story of the head of the ESL department in her school. One Canadian student complained in the school newspaper that an ESL student with whom he was to work on a project brought an interpreter with him because he still had trouble communicating in English. The Canadian student argument was that people who had been here for a few years ought to be able to speak English fluently and that if they couldn't, there was something wrong with them. Not surprisingly, this article angered the head of the ESL department. But what is unique about this incident is the way the teacher turned her anger into a constructive action. She summoned several of 
her ESL students to write about their experience of learning English, gathered their stories, and wrote an article for the same school newspaper, explaining how complex and difficult the task of learning a second language was. Her action enabled ESL students' voices to reach the wider school community.

On a smaller scale too individual teachers' care can make a difference for ESL students. Ritsuko, for example, remembers her human society teacher who took extra care to highlight her presence in the non-ESL class. Joining the classroom discussion is a difficult task for many ESL students, who tend to be more self-conscious about their English in the presence of native-speaking students. Whenever Ritsuko had difficulty catching the right moment to speak up, the teacher would name her over other students, saying, "Let's hear what Ritsuko has to say." As well, Saori's grade 7 teacher in Atlanta knew that she would not yet fare well in the non-ESL setting and always gave her a copy of all the answers for an exam one day before it was administered to the class so that she would not have to feel embarrassed. Both are instances of teacher caring: one came out as an effort to include a less visible student in the classroom community and the other as an act of respecting a student's dignity.

We must note, however, that teachers' protective attitudes can sometimes do more harm to ESL students than good: For example, Ritsuko said that some of her ESL teachers were so worried about their students that they were reluctant to send them off to the general program. When the students initiated the change to move on, they often discouraged them by saying that they were not yet ready. These teachers no doubt thought it in the best interest of their students. However, it resulted in the students lingering in the ESL program when it was meant to be a transitional step to the non-ESL program (see the section Subject Matter above). It also points to a lack of interest and shared sense of responsibility on the part of non-ESL teachers, when in fact "responsibility for the language development of students in Ontario schools rest with all teachers in all subject areas" (Ontario Ministry of Education 1988, p. 7, emphasis added).

In short, the above account indicates that the teachers, just like the milieu, have the potential of both facilitating ESL students' growth and hindering it. Although teacher caring is crucial, it is important to acknowledge that it is only part of the equation; the other part is to enable the students to acquire English skills-both social and academic-sufficient for integration. For this purpose, there need to be more organizational efforts through preservice and inservice training to provide individual teachers with concrete strategies for promoting ESL students' language development. Unfortunately, at present teacher education institutions "treat issues related to ESL students as marginal" and "send new teachers into the classroom with minimal information regarding patterns of language and emotional development among ESL 
students and few pedagogical strategies for helping students learn" (Cummins, 1992, pp. 2-3). There is a strong call for mandating ESL training for all prospective teachers (Elson, 1994; Zanini, 1994). Enhanced professional development opportunities are required to help ESL teachers reexamine their own motivation as well as the benefits of their ESL students moving on the one hand, and to initiate non-ESL teachers to take more responsibility and interest in ESL education on the other.

Another area teacher education could focus on is collaborative modes of teaching (Meyers, 1994). Collaboration between ESL and subject area teachers is of increasing importance as the ESL curriculum moves in the direction of integrating language development and content learning. It has been suggested, however, that successful partnerships are hard to come by (Cummins, 1994; Zanini, 1994). The teacher collaboration in Tang's study (1994) was successful, the author says, "because [the teachers] had chosen to enter into the collaborative teaching arrangement, thus enabling them to work in an atmosphere of trust and mutual respect" (p. 114). Such collegiality would be impossible if, for instance, the ESL teacher is treated as a convenient teaching assistant for the subject area teacher. Both parties must approach collaboration by acknowledging that each has expertise that complements that of the other.

\section{Conclusion}

The ESL curriculum seen from the ESL students' standpoint reveals quite a different picture from that viewed from the usual top-down perspective. From the educators' point of view, "English-language acquisition is viewed as the single most important educational goal for this student group" (PeaseAlvarez \& Hakuta, 1992, p. 5). However, when we turn our attention to the students' experience of the curriculum, it becomes evident that English acquisition in the ESL curriculum cannot be treated separately from the larger issue of ESL students' personal and educational growth. The following major points have emerged from our analysis.

Learner. The ESL students' previous experiences and identities have a large impact on their current learning. Differential motivation to learn English among the students depends largely on the degree of their desire to gain entry to the English-speaking community in school and their perceived need of English to achieve this end.

Subject matter. The usual ESL curriculum designed to develop basic academic skills in English may not be of much help to ESL students who already possess highly developed literacy skills in their first language. They seem to have little difficulty transferring these skills to the second language. On the other hand, they may require more assistance with conversation skills with which to establish interpersonal relations with native-speaking peers. 
Milieu. School is a site of both liberation and domination for ESL students. It is a site of liberation because it provides ESL students with a safe place where they can take risks and experiment with the new language without feeling threatened by the prospect of failure. However, it is also a site of domination because relegating students to ESL programs perpetuates their status as second-rate citizens of the school and diminishes their motivation to advance their English beyond the level required in the ESL environment.

Teachers. The presence of a caring teacher makes a substantial difference to ESL students, especially to those who have difficulty establishing rapport with native-English-speaking students. However, teachers' protective attitudes can sometimes delay ESL students' transition to the general program. Teachers' influence seems more positive when they direct their effort into promoting integration among students of all language proficiency levels rather than segregating them. Enhanced teacher education would help involve all teachers in ESL students' education.

Taken together our findings point to the importance of recognizing students as active initiators of their own education. It is important for two reasons. The first is that the students contribute much to shaping the learning that takes place. Even the external conditions of the environment are changed to some degree by what they bring to it. The second is that the students are capable of responding to more challenges in learning than the educators have imagined so far. Our participants' stories suggest that what ESL students really want is education that enables them to grow into competent speakers, while giving them a sense of overcoming a major challenge. As Postman and Weingartner (1969) put it, "Clearly there is no more important function for education to fulfil than that of helping us to recognize the world we actually live in and, simultaneously, of helping us to master concepts that will increase our ability to cope with it" (p. 212).

\section{Acknowledgments}

Preparation of this article was supported in part by a Matsushita International Foundation research grant to Yasuko Kanno. We gratefully acknowledge Susan Davey for her insights and Ritsuko, Saori, Kenta, and Hideki, Jim Cummins, and the editors of TESL Canada Journal for their thoughtful comments on earlier drafts of this article. A warm thanks also goes to Michael Connelly for introducing Schwab's four commonplaces to us.

\section{Notes}

${ }^{1}$ An earlier version of this article was presented at TESL Ontario '93, Toronto, 25-27 November 1993.

${ }^{2}$ Chinese immigrants in particular are by far the fastest growing ethnic group in Canada according to the 1991 census (McInnes, 1993).

${ }^{3}$ One caveat for teachers who would like to initiate a mixed buddy system: it is important to be careful not to have either student feel solely responsible for everything in the other person's life. Such overdependence could seriously diminish the value of peer buddying, leaving one party feeling neglected and the other overburdened. 


\section{The Authors}

Yasuko Kanno and Sheila Dermer Applebaum are doctoral students in the Department of Curriculum at the Ontario Institute for Studies in Education. Yasuko's doctoral work is on the experience and identity transition of Japanese returnee students; she also teaches Japanese part time at the University of Toronto. Sheila is an administrator for adult ESL and native languages instruction programs at the Toronto Board of Education. Her interests include teacher education and collaborative management models.

\section{References}

Brislin, R.W. (1981). Cross-cultural encounters: Face-to-face interaction. New York: Pergamon Press.

Collier, V.P. (1987). Age and rate of acquisition of second language for academic purposes. TESOL Quarterly, 21, 617-641.

Conle, C. (1992). Language, experience, and negotiation. Curriculum Inquiry, 22, 165-190.

Connelly, D.M., \& Clandinin, D.J. (1988). Teachers as curriculum planners. Toronto/New York: OISE Press/Teachers College Press.

Cummins, J. (1979). Linguistic interdependence and the educational development of bilingual children. Review of Educational Research, 49, 222-251.

Cummins, J. (1984). Bilingualism and special education: Issues in assessment and pedagogy. Clevedon, UK: Multilingual Matters.

Cummins, J. (1989). Empowering minority students. Sacramento, CA: California Association for Bilingual Education.

Cummins, J. (1992, November). Negotiating identities in the ESL classroom. Paper presented at TESL Ontario Conference, Toronto. @REF = Cummins, J. (1994, November). Equity issues related to ESL/ESD provision. Paper presented at the Symposium on Integration Issues, TESL Ontario Conference, Toronto.

Dewey, J. (1938/1963). Experience and education. New York: Macmillan.

Dunbar, S. (1992). Developing vocabulary by integrating language and content. TESL Canada Journal, 9(2), 73-79.

Early, M. (1992). Aspects of becoming an academically successful ESL student. In B. Burnaby \& A. Cumming (Eds.), Socio-political aspects of ESL (pp. 265-275). Toronto, ON: OISE Press.

Early, M., Mohan, B.A., \& Hooper, H.R. (1989). The Vancouver school board language and content project. In J.H. Esling (Eds.), Multicultural education and policy: ESL in the 1990s (pp. 107-122). Toronto, ON: OISE Press.

Early, M., \& Tang, G.M. (1991). Helping ESL students cope with content-based texts. TESL Canada Journal, 8(2), 34-44.

Elson, N. (1994, November). TESL education and training in Faculties of Education. Paper presented at the Symposium on Integration Issues, TESL Ontario Conference, Toronto.

Employment and Immigration Canada. (1992). Language instruction for newcomers to Canada. Ottawa: Author.

Erickson, F., \& Shultz, J. (1991). Students' experience of the curriculum. In P.W. Jackson (Eds.), Handbook of research on curriculum: A project of the American Educational Research Association (pp. 465-485). New York: Macmillan.

Furnham, A., \& Bochner, S. (1986). Culture shock: Psychological reactions to unfamiliar environments. London: Routledge.

Gardner, R., \& Lambert, W. (1959). Motivational variables in second language acquisition. Canadian Journal of Psychology, 13, 266-272.

Handscombe, J. (1989). Mainstreaming: Who needs it? In J.H. Esling (Eds.), Multicultural education and policy: ESL in the 1990s (pp. 18-35). Toronto: OISE Press.

Harklau, L. (1994). ESL versus mainstream classes: Contrasting L2 learning environments. TESL Quarterly, 28, 241-272. 
Klein, M.H., Alexander, A.A., \& Tseng, K.-H. (1971). The foreign students adaptation program: Social experience of Asian students. International Educational and Cultural Exchange, 6(3), 77-90.

Larsen-Freeman, D. (1991). Second language acquisition research: Staking out the territory. TESOL Quarterly, 25, 315-350.

McInnes, C. (1993, February 24). Census balance shifts away from French, British origins. The Globe and Mail, p. A14.

McLaren, P. (1989). Life in schools: An introduction to Critical Pedagogy in the foundation of education. Toronto: Irwin.

Mead, G.H. (1934). Mind, Self and society: From the standpoint of a social behaviorist. Chicago, IL: University of Chicago Press.

Meyers, M. (1994, November). Clear understanding of the term, integration. Paper presented at the Symposium on Integration Issues, TESL Ontario Conference, Toronto.

Ontario Ministry of Education (1988). English as a second language and English skills development: Intermediate and senior division. Toronto, ON: Author.

Pease-Alvarez, L., \& Hakuta, K. (1992). Enriching our views of bilingualism and bilingual education. Educational Researcher, 21(2), 4-6.

Postman, M., \& Weingartner, C. (1969). Teaching as a subversive activity. New York: Delacorte Press.

Saville-Troike, M. (1984). What really matters in second language learning for academic achievement. TESOL Quarterly, 18, 199-219.

Schwab, J.J. (1971). The practical: Arts of eclectic. School Review, 79, 493-542.

Schwab, J.J. (1973). The practical 3: Translation into curriculum. School Review, 81, 501-522.

Swain, M. (1985). Communicative competence: Some roles of comprehensible input and comprehensible output in its development. In S.M. Gass \& C.G. Madden (Eds.), Input in second language acquisition (pp. 235-253). Rowley, MA: Newbury House.

Tang, G.M. (1994). Teaching collaboration in integrating language and content. TESL Canada Journal, 11(2), 100-116.

Taylor, C. (1992). Multiculturalism and "the politics of recognition." Princeton, NJ: Princeton University Press.

Toohey, K. (1992). We teach English as a second language to bilingual students. In B. Burnaby \& A. Cumming (Eds.), Socio-political aspects of ESL (pp. 87-96). Toronto, ON: OISE Press.

Toronto Board of Education. (1988). Final report of the Work Group on English as a Second Language. Toronto, ON: Author.

Toronto Board of Education. (1991). Task force $V$ on the young adolescent learner. Toronto, ON: Author.

Wong Fillmore, L. (1983). The language learner as an individual: Implications of research on individual differences for the ESL teacher. In M.A. Clark \& J. Handscombe (Eds.), On TESOL '82: Pacific perspective on language learning and teaching (pp. 157-173). Washington, DC: TESOL.

Wong Fillmore, L. (1989). Teaching English through content: Instructional reform in programmes for language minority students. In J.H. Esling (Eds.), Multicultural education and policy: ESL in the 1990s (pp. 125-143). Toronto, ON: OISE Press.

Wong Fillmore, L., \& Meyer, L.M. (1992). The curriculum and linguistic minorities. In P.W. Jackson (Eds.), Handbook of research on curriculum: a project of the American Educational Research Associations (pp. 626-658). New York: Macmillan.

Zanini, F. (1994, November). Classroom teacher guidance. Paper presented at the Symposium on Integration Issues, TESL Ontario Conference, Toronto. 